\title{
Observing Geohazards from Space
}

\author{
Francesca Cigna \\ Italian Space Agency (ASI), Via del Politecnico s.n.c., 00133 Rome, Italy; francesca.cigna@asi.it \\ Received: 27 January 2018; Accepted: 5 February 2018; Published: 8 February 2018
}

\begin{abstract}
With a wide spectrum of imaging capabilities-from optical to radar sensors, low to very high resolution, continental to local scale, single-image to multi-temporal approaches, yearly to sub-daily acquisition repeat cycles-Earth Observation (EO) offers several opportunities for the geoscience community to map and monitor natural and human-induced Earth hazards from space. The Special Issue "Observing Geohazards from Space" of Geosciences gathers 12 research articles on the development, validation, and implementation of satellite EO data, processing methods, and applications for mapping and monitoring of geohazards such as slow moving landslides, ground subsidence and uplift, and active and abandoned mining-induced ground movements. Papers published in this Special Issue provide novel case studies demonstrating how EO and remote sensing data can be used to detect and delineate land instability and geological hazards in different environmental contexts and using a range of spatial resolutions and image processing methods. Remote sensing datasets used in the Special Issue papers encompass satellite imagery from the ERS-1/2, ENVISAT, RADARSAT-1/2, and Sentinel-1 C-band, TerraSAR-X and COSMO-SkyMed X-band, and ALOS L-band SAR missions; Landsat 7, SPOT-5, WorldView-2/3, and Sentinel-2 multi-spectral data; UAV-derived RGB and near infrared aerial photographs; LiDAR surveying; and GNSS positioning data. Techniques that are showcased include, but are not limited to, differential Interferometric SAR (InSAR) and its advanced approaches such as Persistent Scatterers (PS) and Small Baseline Subset (SBAS) methods to estimate ground deformation, Object-Based Image Analysis (OBIA) to identify landslides in high resolution multi-spectral data, UAV and airborne photogrammetry, Structure-from-Motion (SfM) for digital elevation model generation, aerial photo-interpretation, feature extraction, and time series analysis. Case studies presented in the papers focus on landslides, natural and human-induced subsidence, and groundwater management and mining-related ground deformation in many local to regional-scale study areas in Austria, Belgium, Italy, Slovakia, Spain, and the UK.
\end{abstract}

Keywords: natural hazards; landslides; subsidence; ground deformation; mining; object-based classification; InSAR; aerial photography; LiDAR; photogrammetry

\section{An Overview of the Special Issue}

Geohazards, such as landslides, volcanoes, earthquakes, tsunamis, ground subsidence, and uplift, pose significant risks to human life and property. Even when not with catastrophic consequences, or when characterised by relatively slow onset and evolution, these processes may be damaging over long periods. Human interaction with the environment may also combine with natural processes and thus trigger acceleration or exacerbate the impacts of geohazards on the built environment.

With a wide spectrum of imaging capabilities-from optical to radar sensors, low to very high resolution, continental to local scale, single-image to multi-temporal approaches, yearly to sub-daily acquisition repeat cycles-Earth Observation (EO) now offers several opportunities for the geoscience community to map and monitor natural and human-induced Earth hazards from space. 
The Special Issue "Observing Geohazards from Space" of Geosciences encompasses 12 open access papers presenting research studies based on the exploitation of a broad range of EO data and techniques, as well as focusing on a well-assorted sample of geohazard types.

Table 1 summarizes the distribution of data and techniques used in each paper and the target geohazard types detected or monitored, and also provides the DOI and links to each paper to ease direct access by the readers.

Table 1. Overview of Earth Observation (EO) data, methods, and geohazard types that are discussed in the 12 open access research papers composing the Special Issue "Observing Geohazards from Space" of Geosciences. Access links to each paper are also provided via their unique DOI numbers. Papers are sorted in ascending order according to their publication date.

\begin{tabular}{|c|c|c|c|}
\hline $\begin{array}{c}\text { Paper Reference \& DOI with } \\
\text { Access Link }\end{array}$ & $\begin{array}{c}\text { EO and Remote Sensing } \\
\text { Data }\end{array}$ & $\begin{array}{l}\text { Processing and } \\
\text { Analysis Methods }\end{array}$ & Geohazard Types \\
\hline $\begin{array}{c}\text { Novellino et al. [1] } \\
10.3390 / \text { geosciences7020019 }\end{array}$ & Sentinel-1 satellite SAR & Intermittent SBAS InSAR & $\begin{array}{c}\text { mining-related } \\
\text { subsidence and uplift }\end{array}$ \\
\hline $\begin{array}{c}\text { Solari et al. [2] }{ }^{*} \\
10.3390 / \text { geosciences7020021 }\end{array}$ & $\begin{array}{c}\text { COSMO-SkyMed and } \\
\text { RADARSAT-2 satellite SAR }\end{array}$ & SBAS InSAR & $\begin{array}{l}\text { urbanization-related } \\
\text { subsidence }\end{array}$ \\
\hline $\begin{array}{c}\text { Bonì et al. [3] } \\
10.3390 / \text { geosciences7020025 }\end{array}$ & $\begin{array}{c}\text { ERS-1/2, RADARSAT-1, } \\
\text { ENVISAT, ALOS and } \\
\text { COSMO-SkyMed } \\
\text { satellite SAR }\end{array}$ & $\begin{array}{l}\text { StaMPS, SPN, } \\
\text { SqueeSAR }{ }^{\mathrm{TM}} \text { and } \\
\text { IPTA InSAR }\end{array}$ & $\begin{array}{c}\text { groundwater } \\
\text { management-related } \\
\text { subsidence and uplift }\end{array}$ \\
\hline $\begin{array}{c}\text { Cencetti et al. [4] } \\
\text { 10.3390/geosciences7020030 }\end{array}$ & $\begin{array}{l}\text { Google and Bing satellite } \\
\text { optical data, aerial and } \\
\text { ortho-photographs }\end{array}$ & $\begin{array}{l}\text { multi-temporal } \\
\text { photo-interpretation, } \\
\text { feature extraction }\end{array}$ & $\begin{array}{l}\text { landslide dams, river } \\
\text { erosion and debris } \\
\text { transport }\end{array}$ \\
\hline $\begin{array}{c}\text { Fernández et al. [5] } \\
\text { 10.3390/geosciences7020032 }\end{array}$ & $\begin{array}{l}\text { aerial panchromatic and } \\
\text { RGB-NIR photographs, } \\
\text { LiDAR, GNSS }\end{array}$ & $\begin{array}{c}\text { photogrammetry, DEM } \\
\text { generation }\end{array}$ & landslides \\
\hline $\begin{array}{c}\text { Moretto et al. [6] } \\
10.3390 \text { / geosciences7020036 }\end{array}$ & $\begin{array}{c}\text { satellite SAR } \\
\text { data (simulated) }\end{array}$ & $\begin{array}{l}\text { InSAR (simulated) } \\
\text { post-processing }\end{array}$ & landslides \\
\hline $\begin{array}{c}\text { Hölbling et al. [7] * } \\
\text { 10.3390/geosciences7020037 }\end{array}$ & $\begin{array}{l}\text { Landsat 7, WorldView-2/3, } \\
\text { SPOT-5 and Sentinel-2 } \\
\text { satellite optical data }\end{array}$ & $\begin{array}{l}\text { object-based image } \\
\text { analysis OBIA, } \\
\text { photo-interpretation }\end{array}$ & landslides \\
\hline $\begin{array}{c}\text { Cigna et al. [8] } \\
\text { 10.3390/geosciences7030051 }\end{array}$ & $\begin{array}{c}\text { ERS-1/2 satellite SAR, small } \\
\text { UAV aerial RGB-NIR } \\
\text { photographs, GNSS }\end{array}$ & $\begin{array}{l}\text { SBAS InSAR, SfM, } \\
\text { photo-interpretation, } \\
\text { DEM generation }\end{array}$ & $\begin{array}{l}\text { mine collapse, landslides, } \\
\text { natural compaction }\end{array}$ \\
\hline $\begin{array}{c}\text { Gee et al. [9] * } \\
10.3390 / \text { geosciences7030085 }\end{array}$ & $\begin{array}{l}\text { ERS-1/2, ENVISAT and } \\
\text { Sentinel-1 satellite SAR }\end{array}$ & Intermittent SBAS InSAR & $\begin{array}{c}\text { mining-related } \\
\text { subsidence and uplift }\end{array}$ \\
\hline $\begin{array}{c}\text { Czikhardt et al. [10] } \\
\text { 10.3390/geosciences7030087 }\end{array}$ & $\begin{array}{c}\text { Sentinel-1 satellite SAR, } \\
\text { LiDAR, UAV } \\
\text { aerial photographs }\end{array}$ & $\begin{array}{l}\text { StaMPS InSAR, SfM, } \\
\text { DEM generation }\end{array}$ & $\begin{array}{l}\text { landslides, } \\
\text { mining-related } \\
\text { subsidence }\end{array}$ \\
\hline $\begin{array}{c}\text { Declercq et al. [11] } \\
\text { 10.3390/geosciences7040115 }\end{array}$ & $\begin{array}{c}\text { ERS-1/2, ENVISAT, } \\
\text { TerraSAR-X and Sentinel-1 } \\
\text { satellite SAR }\end{array}$ & $\begin{array}{l}\text { StaMPS InSAR, } \\
\text { SARProZ PS }\end{array}$ & $\begin{array}{l}\text { groundwater } \\
\text { management-related } \\
\text { uplift, natural } \\
\text { compaction }\end{array}$ \\
\hline $\begin{array}{c}\text { Matano et al. [12] } \\
\text { 10.3390/geosciences8010008 }\end{array}$ & $\begin{array}{l}\text { ERS-1/2, RADARSAT- } 1 \text { and } \\
\text { ENVISAT satellite SAR }\end{array}$ & $\begin{array}{l}\text { PS-InSAR }{ }^{\mathrm{TM}} \\
\text { PSP-DIFSAR }\end{array}$ & $\begin{array}{l}\text { natural compaction and } \\
\text { human-induced } \\
\text { subsidence, } \\
\text { tectonic uplift }\end{array}$ \\
\hline
\end{tabular}

${ }^{*}$ Invited Feature Papers.

\subsection{Data, Methods and Geohazard Domains}

In their Invited Feature Paper, Hölbling et al. [7] present a spatial accuracy assessment of landslide detection and delineation via semi-automated Object-Based Image Analysis (OBIA). The authors process a set of multi-spectral EO data from the Landsat 7, SPOT-5, WorldView-2/3, and Sentinel-2 missions by using image segmentation and OBIA in five study areas in the Alps in Austria and Italy. Comparison of the OBIA-generated landslide maps with the outcomes from visual image interpretation 
of the same EO data allows them to identify and discuss in detail the potentials and limitations of the two approaches (visual and semi-automated) and to demonstrate that both methods produce similar results when the same data basis is used.

Keeping the focus on landslide analysis with EO and remote sensing data, by means of an assorted, 60-year long temporal stack of satellite imagery, ortho-photographs, and aerial photographs, Cencetti et al. [4] study the Costantino landslide (Italy) that dammed the Bonamico River Valley in 1973 and caused the formation of a $175,000 \mathrm{~m}^{2}$ lake. A combined approach of photo interpretation, analysis of climate records, and assessment of wet/drought periods allows the authors to examine the evolution of the lake surface and landslide dam and, in particular, to reconstruct the natural filling of the lake via river debris transport and accumulation, as well as dam overtopping and failure, and to sense the lake extinction in recent years.

Going back to similar historical times, Fernández et al. [5] use a 54-year long multi-temporal set of photogrammetric flights for the generation of Digital Terrain Models (DTM) to analyse the evolution of the Almegijar rock slide in Spain. The authors exploit an aerial digital camera with four spectral bands (i.e., visible RGB, and near-infrared NIR), a Light Detection and Ranging (LiDAR) sensor, and in-flight orientation based on Global Navigation Satellite System (GNSS) onboard a 2010 flight to generate a high-precision DTM that they then use as a reference for comparison with other elevation models generated based on historical panchromatic flights. Differential DTMs, cross sections, and volumetric changes are computed to identify depletion and accumulation areas and to estimate landslide movement rates and activity.

Moving from optical to Synthetic Aperture Radar (SAR) satellite imagery, the Invited Feature Paper by Gee et al. [9] presents a multi-mission study of land motion and groundwater level change in areas of abandoned mining in the UK using a 21-year long series of ERS-1/2, ENVISAT and Sentinel-1 satellite SAR data in C-band. The authors employ a modified version of the Small BAseline Subset (SBAS) technique allowing extraction of ground motion information across most land cover types, and identify surface depressions in proximity to former collieries and broad areas experiencing regional scale uplift. The latter often occurs in previously mined areas where groundwater levels rise following the cessation of groundwater pumping after mine closure.

The extensive spatial coverage, regular temporal sampling, and free data availability of Sentinel-1 are further discussed in the paper by Czikhardt et al. [10], who provide an in-depth multi-temporal study of recent ground stability and movements for a $440 \mathrm{~km}^{2}$ study region in Slovakia characterised by high landslide susceptibility and intensive brown coal mining. The authors combine two open-source processing tools, i.e., the Sentinel Application Platform (SNAP) and Stanford Method for Persistent Scatterers (StaMPS), and compare their satellite-based observations with ground truth data from borehole inclinometers and terrestrial levelling to estimate the accuracy of the Sentinel-1 InSAR results. The use of consistent Sentinel-1 stacks in both ascending and descending modes, along with motion decomposition along the vertical and horizontal components, allows the authors to demarcate distinct small-areas of spatially clustered motion due to the presence of slope instability and severe land subsidence due to undermining. This result is also confirmed based on the comparison of Unmanned Aerial Vehicle (UAV) and LiDAR-derived 3D elevation models.

With a similar combination of EO and remote sensing techniques, Cigna et al. [8] discuss how to enhance the understanding of historical ground stability and motion in areas of geotechnical infrastructure and abandoned salt mine workings by means of satellite InSAR and tailored small UAV surveying. With a $3000 \mathrm{~km}^{2}$ study area in Co. Antrim (UK), the authors utilise ERS-1/2 SBAS InSAR to achieve a baseline ground instability scenario over wide areas encompassing several elements at risk and strategic infrastructure. To detect localised deformation and indicators of ground instability, the InSAR-derived baseline is integrated with analysis of very high resolution ortho-photographs and 3D surface models generated via Structure-from-Motion (SfM). Links to access the 3D model and ortho-photographs for a salt mine collapse site within the study site are also provided as appendices to the paper. 
With a focus on land subsidence, in their Invited Feature Paper Solari et al. [2] apply the well-established SBAS algorithm to quantify recent (2011-2014) subsidence rates and temporal evolution in the urban area of Pisa (Italy) using two stacks of RADARSAT-2 C-band and COSMO-SkyMed X-band satellite SAR imagery. From their InSAR analysis at the local and building scales in relation to information on the recent evolution of the city, the authors detect an apparent correlation between subsidence rates and location of modern urban development areas. Their study demonstrates that the construction of new buildings acts as the trigger for accelerated consolidation of highly compressible layers onto which the urban fabric of the city is built.

With an analogous objective, the paper by Declercq et al. [11] provides a 25-year long (1992-2017) study of ground instability for the city of Brussels (Belgium) through combination of C- and X-band satellite SAR data from the ERS-1/2, ENVISAT, TerraSAR-X, and Sentinel-1 missions. A total of $\sim 300$ scenes are processed with Persistent Scatterers (PS) methods to extract deformation time series and detect the evolution of ground deformation. The authors find evidence of ongoing, slow ground deformations in particular in the historic centre, where land uplift occurs as a result of a reduction of groundwater extraction from deep aquifers and consequent groundwater level rise related to deindustrialization, as confirmed by piezometric data. Natural settlement of soft alluvial deposits along river valleys, possibly increased by the load of buildings, is also detected.

Looking at a whole alluvial plain susceptible to land subsidence and coastal hazards, Matano et al. [12] use almost two decades of InSAR information (1992-2010) derived from the ERS-1/2, ENVISAT and RADARSAT-1 C-band SAR missions to detect subsidence trends of the Volturno River Coastal Plain (Italy). The authors interpret and post-process six datasets of Permanent Scatterers InSAR (PS-InSAR) and Persistent Scatterer Pairs (PSP) results to derive maps of vertical deformation and identify significant subsidence rates in the central axial sectors and the river mouth area, and some uplift related to tectonic activity in the eastern part of the plain. The analysis of subsoil stratigraphy allows them to infer that subsidence is mainly due to natural compaction of the fluvial and palustrine deposits, with anthropogenic influences such as groundwater exploitation and urbanization in some sectors of the study area acting as an additional geohazard factor.

Bonì et al. [3] tackle the use of satellite InSAR methods and SAR data from the methodological point of view, and present three case studies in Italy, Spain, and the UK, where approaches to analysing and interpreting InSAR results for land subsidence detection, characterisation, and modelling are exploited with a focus on the relationship of surface deformation with groundwater level change and exploitation of aquifer resources. Using various stacks of C-, L- and X-band satellite SAR imagery, as well as different InSAR image processing methods (i.e., SqueeSAR ${ }^{\mathrm{TM}}$, StaMPS, Stable Points Network or SPN, and Interferometric Point Target Analysis or IPTA), the authors showcase InSAR time series post-processing methods such as principal component analysis to identify and separate linear, non-linear, and seasonal movements, transient and inelastic aquifer deformation, and accelerating and decelerating subsidence trends.

Looking at the applicability of satellite InSAR methods for geohazard mapping and monitoring, an approach to mapping a priori the feasibility of SAR imaging and InSAR monitoring of land deformation is presented by Novellino et al. [1]. With a focus on the Sentinel-1 SAR constellation, the authors build upon the InSAR feasibility assessment developed in [13] for the ERS-1/2 and ENVISAT missions and run an analysis of Sentinel-1 data availability, topographic distortions, and land cover constraints toward the use of a novel SBAS algorithm to sense ground stability and motion across a whole country. The aspect of achievable standard deviation in the derived InSAR velocities is also discussed to showcase the importance of consistent time stacks of SAR data as inputs for advanced InSAR methods to generate robust geohazard information.

With a specific look at landslide phenomena, on the other hand, Moretto et al. [6] explore the potential of satellite InSAR methods to sense pre-failure landslide movements and to feed into failure forecasting methods. For 56 landslide sites with monitoring data available in the scientific literature, the authors collate pre-failure deformation information from on site and remote monitoring 
instruments, such as inclinometers, ground-based InSAR, and total station, and resample the frequency of these records to simulate satellite acquisition parameters (e.g., revisit times and phase ambiguity). Their analysis reveals that InSAR could successfully support monitoring of landslide tertiary creep, and in some cases, the time of failure as well. However, for the purposes of risk management and early warning, it is extremely important for future satellite SAR missions to provide high data sampling frequencies (i.e., short revisit times) to capture pre-failure landslide dynamics.

\subsection{Statistics, Bibliometrics and Impact}

The 12 research papers were published in the Special Issue between the end of March 2017 and early January 2018, with an average time of about two months from first submission to online publication. Each manuscript was assessed via rigorous peer-reviewing from two or more esteemed experts in the respective field [14].

Based on MDPI's article metrics powered by TrendMD, since the publication of the first paper in March 2017 and as of the beginning of 2018 the Special Issue received more than 10,000 views totally, and is now reached by $\sim 35$ readers/day on average. A widespread geographic distribution of readers across the globe is observed, with apparent peaks in the USA, Asia and Europe.

Overall, the published papers already received five citations in the indexed literature in the first few months after publication, proving the immediate impact of the published research. In particular, three out of five of the latter citations were received by the first paper of the Special Issue that was published in March 2017 [1], and four out of five citations were made by papers published in other scientific journals in the field of remote sensing, EO, and Earth sciences.

\section{Further Reading}

Readers interested in the use of geospatial and remote sensing data and methods for the investigation of natural hazards and disasters, in addition to this Special Issue, can also refer to papers published in other recent Special Issues of Geosciences such as "Mapping and Assessing Natural Disasters Using Geospatial Technologies" collecting articles published in 2016-2017 [15], "Advances in Remote Sensing and GIS for Geomorphological Mapping" published in 2015-2016 [16], "Remote Sensing and Geosciences for Archaeology" published in 2017 [17], and "Geological Mapping and Modeling of Earth Architectures" published in 2014-2016 [18].

In these Issues, several examples of exploitation of EO and other geospatial data and applications are presented, including use of airborne hyperspectral data, detection of hotspots and thermal anomalies, GIS-based hazard and risk assessment, and geological, structural, and geomorphological mapping. Similarly, other natural hazards and surface processes are covered, such as floods, droughts, fires, tectonics, karst, and ground dissolution, as well as human-induced hazards and threats to urban areas and heritage assets.

Acknowledgments: The Guest Editor would like to acknowledge all the authors for contributing to the Special Issue and the anonymous peer reviewers for assessing the submitted manuscripts and greatly helping the authors to enhance the scientific quality of their papers. Sincere gratitude goes to the Editorial Board and Office of Geosciences, especially Assistant Editor Veronica Wang, for the invaluable help and assistance provided at all stages of the design, management, and publication of this Special Issue.

Author Contributions: Following on from the invitation of Jesus Martínez-Frías, Editor-in-Chief of Geosciences, Francesca Cigna designed this Special Issue, served as Lead Guest Editor, and wrote this Editorial.

Conflicts of Interest: The author declares no conflict of interest.

\section{References}

1. Novellino, A.; Cigna, F.; Brahmi, M.; Sowter, A.; Bateson, L.; Marsh, S. Assessing the feasibility of a national InSAR ground deformation map of great britain with sentinel-1. Geosciences 2017, 7, 19. [CrossRef] 
2. Solari, L.; Ciampalini, A.; Raspini, F.; Bianchini, S.; Zinno, I.; Bonano, M.; Manunta, M.; Moretti, S.; Casagli, N. Combined Use of C- and X-Band SAR Data for Subsidence Monitoring in an Urban Area. Geosciences 2017, 7, 21. [CrossRef]

3. Bonì, R.; Meisina, C.; Cigna, F.; Herrera, G.; Notti, D.; Bricker, S.; McCormack, H.; Tomás, R.; Béjar-Pizarro, M.; Mulas, J.; et al. Exploitation of satellite A-DInSAR time series for detection, characterization and modelling of land subsidence. Geosciences 2017, 7, 25. [CrossRef]

4. Cencetti, C.; Di Matteo, L.; Romeo, S. Analysis of Costantino Landslide Dam Evolution (Southern Italy) by Means of Satellite Images, Aerial Photos, and Climate Data. Geosciences 2017, 7, 30. [CrossRef]

5. Fernández, T.; Pérez, J.L.; Colomo, C.; Cardenal, J.; Delgado, J.; Palenzuela, J.A.; Irigaray, C.; Chacón, J. Assessment of the Evolution of a Landslide Using Digital Photogrammetry and LiDAR Techniques in the Alpujarras Region (Granada, Southeastern Spain). Geosciences 2017, 7, 32. [CrossRef]

6. Moretto, S.; Bozzano, F.; Esposito, C.; Mazzanti, P.; Rocca, A. Assessment of Landslide Pre-Failure Monitoring and Forecasting Using Satellite SAR Interferometry. Geosciences 2017, 7, 36. [CrossRef]

7. Hölbling, D.; Eisank, C.; Albrecht, F.; Vecchiotti, F.; Friedl, B.; Weinke, E.; Kociu, A. Comparing Manual and Semi-Automated Landslide Mapping Based on Optical Satellite Images from Different Sensors. Geosciences 2017, 7, 37. [CrossRef]

8. Cigna, F.; Banks, V.J.; Donald, A.W.; Donohue, S.; Graham, C.; Hughes, D.; McKinley, J.M.; Parker, K. Mapping ground instability in areas of geotechnical infrastructure using satellite InSAR and small UAV surveying: A case study in Northern Ireland. Geosciences 2017, 7, 51. [CrossRef]

9. Gee, D.; Bateson, L.; Sowter, A.; Grebby, S.; Novellino, A.; Cigna, F.; Marsh, S.; Banton, C.; Wyatt, L. Ground motion in areas of abandoned mining: Application of the intermittent SBAS (ISBAS) to the Northumberland and Durham Coalfield, UK. Geosciences 2017, 7, 85. [CrossRef]

10. Czikhardt, R.; Papco, J.; Bakon, M.; Liscak, P.; Ondrejka, P.; Zlocha, M. Ground Stability Monitoring of Undermined and Landslide Prone Areas by Means of Sentinel-1 Multi-Temporal InSAR, Case Study from Slovakia. Geosciences 2017, 7, 87. [CrossRef]

11. Declercq, P.-Y.; Walstra, J.; Gérard, P.; Pirard, E.; Perissin, D.; Meyvis, B.; Devleeschouwer, X. A Study of Ground Movements in Brussels (Belgium) Monitored by Persistent Scatterer Interferometry over a 25-Year Period. Geosciences 2017, 7, 115. [CrossRef]

12. Matano, F.; Sacchi, M.; Vigliotti, M.; Ruberti, D. Subsidence Trends of Volturno River Coastal Plain (Northern Campania, Southern Italy) Inferred by SAR Interferometry Data. Geosciences 2018, 8, 8. [CrossRef]

13. Cigna, F.; Bateson, L.B.; Jordan, C.J.; Dashwood, C. Simulating SAR geometric distortions and predicting Persistent Scatterer densities for ERS-1/2 and ENVISAT C-band SAR and InSAR applications: Nationwide feasibility assessment to monitor the landmass of Great Britain with SAR imagery. Remote Sens. Environ. 2014, 152, 441-466. [CrossRef]

14. Geosciences Editorial Office. Acknowledgement to Reviewers of Geosciences in 2017. Geosciences 2018, 8, 33. [CrossRef]

15. $\mathrm{Pu}, \mathrm{R}$. A Special Issue of Geosciences: Mapping and Assessing Natural Disasters Using Geospatial Technologies. Geosciences 2017, 7, 4. [CrossRef]

16. Propastin, P.; Sheng, Y. Geosciences Special Issue "Advances in Remote Sensing and GIS for Geomorphological Mapping”. Available online: http://www.mdpi.com/journal/geosciences/special_issue s/geomorphological-mapping (accessed on 11 January 2018).

17. Tapete, D. Remote Sensing and Geosciences for Archaeology. Geosciences 2018, 8, 41. [CrossRef]

18. McCaffrey, K. Geosciences Special Issue "Geological Mapping and Modeling of Earth Architectures" Available online: http://www.mdpi.com/journal/geosciences/special_issues/geological-mapping (accessed on 11 January 2018).

(C) 2018 by the author. Licensee MDPI, Basel, Switzerland. This article is an open access article distributed under the terms and conditions of the Creative Commons Attribution (CC BY) license (http://creativecommons.org/licenses/by/4.0/). 